
性に関する実験的榆討

网山大学第二外科

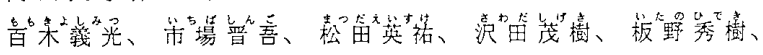

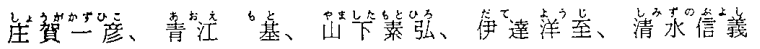

【目的】液体呼吸は、酸素、二酸化炭甞の溶解度の高 いペルフルオロカーホンンの 1 つPFOBを気道注入し换 気を行う新しい人工呼吸法である。我々は、肺虚血彗 潅流障害に対する液体呼吸の有用性について兔を用い 実験的榆討をした。【万法】左肺門クランプにて90分 間虚折の後クランプを解除、同時に右挝問をクランプ して肺虚血再灌流匴害モデルを作成した。このモデル を以下の2群に分けて検討した。1 群: 再潅流後 $\mathrm{FIO} 2=$ 1.0.1回換気量 $7 \mathrm{ml} / \mathrm{kg}$ ，呼吸回数50/分にて掺気を続汀た。 2 群:PFOB7 mlkg 苍気道注入し1群と同じ换気条件にて㬇 起し液体呼吸を行った。さらにコントロール(3群)上 して両肺換気を 90 分間行った後、右肺門をクランプし 同条件で换気した。2 時間経時的に動脈血ガス分析、体、 肺動脈王、気道内压老測定した。HE染色にて肺の組 織学的検討を行った。【結果】 $\mathrm{PaO} 2$ は 2 時關で1详 79 \pm 13 torr、2群 $404 \pm 70^{*} 、 3$ 群 $494 \pm 61$ 。 $\mathrm{PaCO} 2$ 法 2 時問 で 1 群 $61.9 \pm 14.4$ torr、2群 $45.7 \pm 6.1^{*} 、 3$ 群 $32.1 \pm 2.2$ 。 * $(\mathrm{p}<0.05)$ 血行動態は 3 群間に有意差老認めなかった。 組織学的には2 群は1群に比へ障寈が軽度であった。 【結語】肺の虑血再澭流障等に打いて液体呼吸はガス 交換能を有意に改善し、肺の㔍築を保たせた。

\section{E 47} 肺保存におけるnitroglycerin、L-arginineの効果 京都大学胸部疾患研究所呼吸器外科 ${ }^{1)}$ 、ハノーファー一医科 大学胸部外科 ${ }^{2)}$

板東 徹1)、Albes $\mathrm{JM}^{2)}$ 、Schäfers $\mathrm{H}-\mathrm{J}^{2)}$ 、和田洋巳 ${ }^{1)}$

ひとみしけき

人見滋樹 1 )

【目的】一酸化窒素(NO)ドナーであるnitroglycerin(NTG) と血管内皮でのNO産生の基質であるL-arginineの肺保存に おける有効性をラット摘出肺潅流モデルを用いて検討した。

【対象と方法】male inbred SPRDラット(400-520g)を保 存液により、NTG群 $(n=7)$ : Euro-Collins液(EC) + NTG $(100 \mathrm{mg} / \mathrm{L}) 、$ ARG群 $(n=8):$ EC液 + L-arginine $(10 \mathrm{mmol} /$ L)、及びcontrol 群 $(n=8)$ : EC液、の3群に分け、各保存液 で肺をflushし、2時間の冷所保存後に50分間肺機能を評価 した。肺潅流液にはへマトクリット38\%に調製したウシ洗 浄赤血球液を用い、これをdeoxygenatorで脱酸素化し、保 存肺の再潅流を行った。

【結果】NTG群は7匹全て50分間の再潅流が可能だった のに対し、ARG群では8匹中3匹が、control群では8匹中5 匹が高度の肺水腫のため、中途で評価不能となった $(p<$ 0.05: NTG群 vs control群)。NTG群は再海流後の酸素化能(

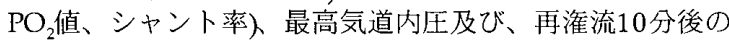
平均肺動脈圧、肺血管抵抗においてcontrol群に比べ有意に 良好な値を示した $(p<0.05)$ 。一方、ARG群は再潅流後の酸 素化能、最高気道内圧、平均肺動脈圧、肺血管抵抗の全て において ontrol群との間に統計学的有意差を認めなかった。

【結諭】ラット摘出肺潅流モデルを用いた肺保存におい て、NTGは有効であったが、L-arginineには有効性は認め られなかった。L-arginineの添加がNO産生に直接結びつか ないことが示唆された。血管内皮細胞内におけるNO生成 障害の可能性が推測された。

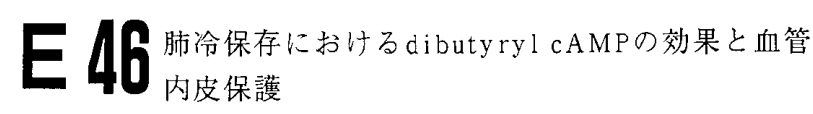
京都大学胸部疢患研究所胸部外科,

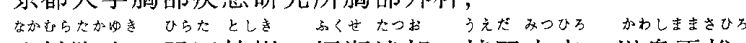
中村隆之, 平田敏樹, 福瀬達郎, 植田充宏, 川島正裕 和田洋已，人見滋樹

【目的】cAMP an alogueとして血管内皮保護作用を示す dibutyryl cAMPの肺冷保存に扔ける効果を検討した。

【方法】ルイスラットが潅流液と虚血（ $4{ }^{\circ} \mathrm{C}, 15$ 時間） の有無により3群（各n=6）に分けられた。fresh群は ET-Kyoto（ET-K）液でラット肺をフラッシュし心肺ブ ロックを摘出後, 直ちに左肺を再潅流した。 ET・K液は細 胞外液型電解質組成, 非還元性二糖類 treh aloseお よび hydroxyetyl starch（HES）を特徽とする臓器保存液で あり，われわれは肺保存におけるその有效性を報告して きた。 ET·K群はET-K液で, db-cAMP群はET-K液十 dibutyryl cAMP ( $2 \mathrm{mM})$ でラット肺をフラッシュし, $4^{\circ} \mathrm{C} て ゙ 15$ 時間保存した後, 再潅流を行った。再潅流はex vivoラット肺潅流モデルを用い， $100 \% \mathrm{O}_{2}$ 換気下に60分 間行った、【結果】db-cAMP群の肺シャント率は3〜 $4 \%$ 程度とfresh群のそれと同等でET·K群に比べて有意に低 值であった（ $p<0.01 ）$. 再潅流後の肺組織湿乾重量比

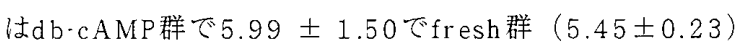
と同等であり, ET-K群 $(14.20 \pm 3.43)$ 上り有意に低值 であった（ $p<0.01 ）$. 透過電子顕微鏡による検討では db-cAMP投与による血管内皮保護効果が認められた。

【結論】dibutyryl cAMPはラット肺冷保存に伴う傷害を 軽減した。
E 48 脱死、心臟死、泠保存の微小血管透過性に 及ぼす影響の実験的検討
岡山大学第二外科

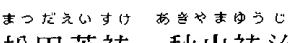 淞田英祐秋山祐治

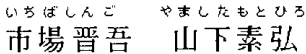

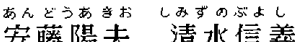

目的; 家患心肺摘出モデルを用い、脳死、心停止後 の温阻血、冷保存の微小血管透過性に及ほすす影響を 蚞討した。方法; 家鬼摘出肺を用い重量法により滤 過率 $(\mathrm{Kf})$ を算出し、微小血管透過性の指標とした。 心拍動群 $(\mathrm{n}=15)$ 、脳死群 $(\mathrm{n}=12)$ 、心停止群 $(\mathrm{n}=12)$ に分计、更に各群に扮いて非保存、6 時間、 24 時間の冷保存に分计冷保存の及漂す影響を経時 的に検討した。結果；心指動群では、6時間保存で は血管透過性の亢進はみられなかったが、24時間 保存では $\mathrm{K}$ f は有意に上昇した。脳死群では、非保 存、6 時間保存までは心拍動群と有意差なく、24 時間保存で有意に $\mathrm{K} \mathrm{f}$ は上昇した。心停止群では、 非保存の段階で－f $\mathbf{f}$ 心拍動群に比し有意に上昇し ており、6時間、24 時間の保存ではさらに京進し tro 